INTERNATIONAL JOURN AL OF RESEARCHES IN BIOSCIENCES, AGRICULTURE AND TECHNOLOGY (c) VISHWASHANTI MULTIPURPOSE SOCIETY (Global Peace Multipurpose Socie ty) R. No. MH-659/13 (N) www.vmsindia.org

\title{
BLUE GREEN ALGAE FROM INDUSTRIAL WASTE CONTAMINATED SOILS OF AHMEDNAGAR DISTRICT
}

\author{
J. B. Cholake ${ }^{1}$, A. R. Tuwar $^{1}$ and R. K. Aher ${ }^{2}$ \\ ${ }^{1}$ Arts, Comme ree \& Science College Sonai, Tal: Newasa, Dist: Ahmednagar, Maharashtra, India. \\ ${ }^{2} \mathrm{New}$ Arts, Commerce and Science College, Parner Tal-, Parner, Dist- Ahemednagar,Maharashtra, India . \\ jayacholake2@gmail.com
}

\begin{abstract}
:
In present study, soils samples from industrial wastes contaminated sites of Ahmednagar district we re collected. The se samples we re taken up for algal analysis. Five gm. of soil samples were cultured using liquid and solid Chu's 10 Medium. Cultures were ke pt under diffused light at room temperature. Periodically algae from culture medium were removed and identified using standard algal monographs. Qualitative algal studies were carried in orde $r$ to understand variations of algal species in industrial wastes contaminated soils. The aim of algal studies was to identify blue green algal species from industrial wastes contaminated soils of Ahmednagar district. In present study 7 Blue green algae (Chroococcus, Microcystis, Oscillatoria, Phormidium, Lyngbya, Nostoc and Haplosiphon) were found in industrial waste contaminated soils of Ahmednagar district.

Keywords: Blue green algae, industrial waste contaminated soil, Chu's 10 Medium and Ahmednagar district.
\end{abstract}

\section{Introduction}

Soil exhibit a rich micro flora comprising of bacteria, fungi, viruses, algae and also other microbes and plays an important role influencing the structure and fertility of soil. The soil blue green algae play an important role in nitroge $\mathrm{n}$ fixation, increases humus content and fertility of soil and improving texture of soil (Fritsch, 1907; Booth, 1941; Lewin, 1956 and Marathe, 1972). Several important works appeared such as (Fritsch, 1907 and 1922; Bristol, 1927; Petersen, 1935; John, 1942 and Fritsch and John, 1942) described algae as colonizes of new ground and contribute to the increase in humus content of soils. Singh, (1950 and 1961) recommended blue green algae for reclamation of alkaline soils. Fritsch, (1922); Fritsch and John, (1942) and Lund, (1962) observed that blue green algae showed preference to the alkaline soil whereas acidic soils show dominance of green algae.

Industrial and municipal wastes contaminated soil may contain a wide range of pollutant, including metals, hydrocarbons, organic matters, pesticides, herbicides etc. release of pollutants to soil. In industrial efflue nts contaminated sites showed blue green species such as Lyngbya, Oscillatoria, Phormidium, Microcystis, Anabaena, Nostoc, Westiellopsis and Synechococcus (Subramaniyan et al., 2007).The losses of fertile agricultural soils have been growing day by day by increasing industrialization. It results mainly deforestation, loss of vegetation and degradation of soil. The industrial wastes reaching land through direct or indirect disposal method and soil and water contamination occurs by adding various types of contaminants. Such practiceshave resulted into change in physical, chemical and biological properties of soil. The soil algal growth depends on soil types. The aim of present study was to identify algal species tolerant and sensitive to indus trial wastes contaminants.

\section{Materials and Methods}

Soil samples were collected from 5 different sugar Industrial regions (i.e Rahuri, Rahata, Pravaranagar, Sangamner \& Sonai) of Ahmednagar District which represented various climatic conditions. The collected soil sampleswere used for analysis studies (Gupta, 2001 and Trivedy and Goel, 1986). colour of soil was examined by visual observation. $\mathrm{PH}_{\mathrm{O}}$ soil samples was measured by $\mathrm{pH}$ meter in laboratory.

2. Preparation of Chu's 10 Medium -

\begin{tabular}{|c|c|}
\hline Salts & Weight \\
\hline Calcium Nitrate $\left(\mathrm{Ca}\left(\mathrm{NO}_{3}\right)_{2} \cdot 4 \mathrm{H}_{2} \mathrm{O}\right)$ & $0.232 \mathrm{gm}$ \\
\hline Dipotassium phosphate $\left(\mathrm{K}_{2} \mathrm{HPO}_{4}\right)$ & $0.01 \mathrm{gm}$ \\
\hline $\begin{array}{l}\text { Magnesium \Sulfate Heptahydrate } \\
\left(\mathrm{MgSO}_{4} \cdot 7 \mathrm{H}_{2} \mathrm{O}\right)\end{array}$ & $0.025 \mathrm{gm}$ \\
\hline Sodium carbonate $\left(\mathrm{Na}_{2} \mathrm{CO}_{3}\right)$ & $0.02 \mathrm{gm}$ \\
\hline $\begin{array}{l}\text { Sodium me tasilicate pentahydrate } \\
\text { (Na2SiO3.5H20) }\end{array}$ & $0.044 \mathrm{gm}$ \\
\hline Ferric citrate (Fe(C6H5O7).xH2O) & $0.0035 \mathrm{gm}$ \\
\hline Citric acid ( $\mathrm{C} 6 \mathrm{H} 8 \mathrm{O} 7$ ) & $0.0035 \mathrm{gm}$ \\
\hline Agar & $15.0 \mathrm{gm}$ \\
\hline Me tal Solution & $1.0 \mathrm{ml}$ \\
\hline Dis tille d water & $1.0 \mathrm{~L}$ \\
\hline
\end{tabular}


Metal Solution

\begin{tabular}{|l|c|}
\hline \multicolumn{1}{|c|}{ Salts } & Weight \\
\hline Boric Acid $\left(\mathrm{H}_{3} \mathrm{BO}_{3}\right)$ & $2.4 \mathrm{gm}$ \\
\hline $\begin{array}{l}\text { Manganese chloride } \\
\text { tetrahydrate }\left(\mathrm{MnCl}_{2} \cdot 4 \mathrm{H}_{2} \mathrm{O}\right)\end{array}$ & $1.4 \mathrm{gm}$ \\
\hline Zinc chloride $\left(\mathrm{ZnCl}_{2}\right)$ & $0.4 \mathrm{gm}$ \\
\hline $\begin{array}{l}\text { Cobalt } \mathrm{Chloride} \mathrm{Hexahydrate} \\
\left(\mathrm{CoCl}_{2} \cdot 6 \mathrm{H}_{2} \mathrm{O}\right)\end{array}$ & $0.02 \mathrm{gm}$ \\
\hline $\begin{array}{l}\mathrm{Copper} \mathrm{Chloride} \text { Dihydate } \\
\left(\mathrm{CuCl}_{2} \cdot 2 \mathrm{H}_{2} \mathrm{O}\right)\end{array}$ & $0.0001 \mathrm{gm}$ \\
\hline Distille d water & $1.0 \mathrm{~L}$ \\
\hline
\end{tabular}

$\mathrm{PH}^{\mathrm{H}}$ was adjusted to 8.5 for Cyanobacteria. The medium was autoclave for $20 \mathrm{~min}$ at $15 \mathrm{lb} \mathrm{s}$ pressure.

\section{Preparation for cultures-}

I. Sterilization of glassware-The glassware was cleaned, oven dried and paper wrapped to glass wares and sterilized at $15 \mathrm{lb}$ pressure for $20 \mathrm{~min}$ in autoclave.

II. Isolation and culture of soil algae - For Isolation of soil algae se rial dilution method was used. Simultaneously petriplates containing solidifying nutrient agar medium were inoculated with $1 \mathrm{ml}$ inoculums from dilution from all 10 tubes. Then petriplates were wrapped by wrap paper and kept in diffused light at room temperature. The algal growths in petriplates were observed periodically up to 3-4 weeks.

For algal culture in liquid medium $5 \mathrm{gm}$.of soil was added to $100 \mathrm{ml}$ liquid medium in cultural bottle. The inoculated bottles were incubated under diffused sunlight at room temperature. The observations we re taken periodically up to 3 months.

III. Algal analysis- For qualitative studies algal slides are prepared and observed under research microscope. Identification of algae was made with the help of standard monographs. (Desikacharya, 1959; Prescott, 1951and Smith1950).The microphotography of soil algae was done simultaneously during study period.

\section{Results and Discussion -}

In present work Industrial wastes contaminated soils showed $\mathrm{p}^{\mathrm{H}}$ in the ranges between 7.11 7.87. In present study observed 7 Blue green algae (Chroococcus, Microcystis, Oscillatoria, Phormidium, Lyngbya, Nostoc and Haplosiphon) were found in industrial wastes contaminated sites of Ahmednagar district. Shapiro and Stadtman (1970), Gantar et.al (1984), Fors berg et al. (1988), Kelly (1988), Xue and Sigg (1990), Ali et al. (1999), Gupta et. al (2001), Adonis and Leonardo (2001), Dwivedi et al. (2005), Rai et al. (2005 and 2007), Singh et al. (2007) and Subramanian et al.(2007) observed that the different groups of algae growing on industrial effluent (Chlorella, Scenedesmus, Chroococcus, Anabaena, Microcystis, Nostoc, Westiellopsis, Synechococcus, Oscillatoria, Spirulina, Gleocapsa, Oedogonium and Spirogyra exhibit high amount of toxic heavy metal (Fe, $\mathrm{Mn}, \mathrm{Cu}$, $\mathrm{Ni}, \mathrm{Zn}$ and $\mathrm{Cr}$ ) accumulation and have been found useful for bioremediation of significant amount of toxic heavy metal pollution in industrial sites. Oscillatoria and Phormidium along with Lyngbya were found dominating all the industrial effluents. Our result shows Oscillatoria and Phormidium were dominant in industrial effluents. Singh and Saxena, (1969), Venkateswarlu (1969), Rai and Kumar (1977), Nazneen (1980), Venuet al. (1984), Anand (1998), Boominathan (2005), Murugesan and Subramanian (2005) and Vijayakumar et al. (2005) reported that the growth of Cyanobacteria than any other algae found in industrial effluent are more. In our work also found the Cyanophycean members were more in ind ustrial wastes contaminated soils.

The work indicated that 7 blue green algae were tolerant in industrial wastes contaminated sites. Oscillatoria are common tolerant algae in industrial wastes contaminated sites. These results indicate that the higher number of species and population of algae indirectly contributing in degradation of contaminants through algal associated saprobic flora.

\section{Summary and Conclusion}

All industrial wastes contaminated soil samples showed alkaline $\mathrm{PH}$. Total 7 Blue green algae (Chroococcus, Microcystis, Oscillatoria, Phormidium, Lyngbya, Nostoc and Haplosiphon) were found in industrial waste contaminated sites. The populations of Oscillatoria were more as compared to other algal population.

\section{Acknowledgement}

Authors are thankful to Savitribai Phule Pune University for financial support to Research and Principal of Arts, Commerce \& Science College Sonai and Principal of New Arts, Commerce and Science College, Parner \& Ahemednagar for providing research facilities. 
1. Culture of soil blue green algae from industrial was te contaminated sites of Ahmednagar district
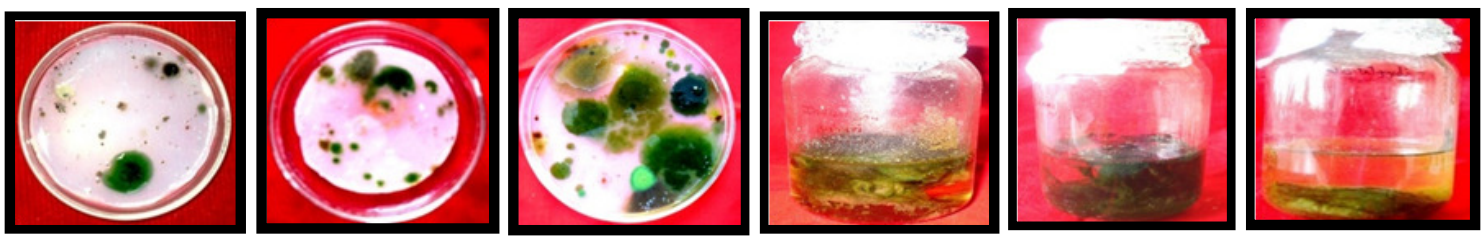

2. Soilblue green algae from industrial waste contaminated sites of Ahmednagar district
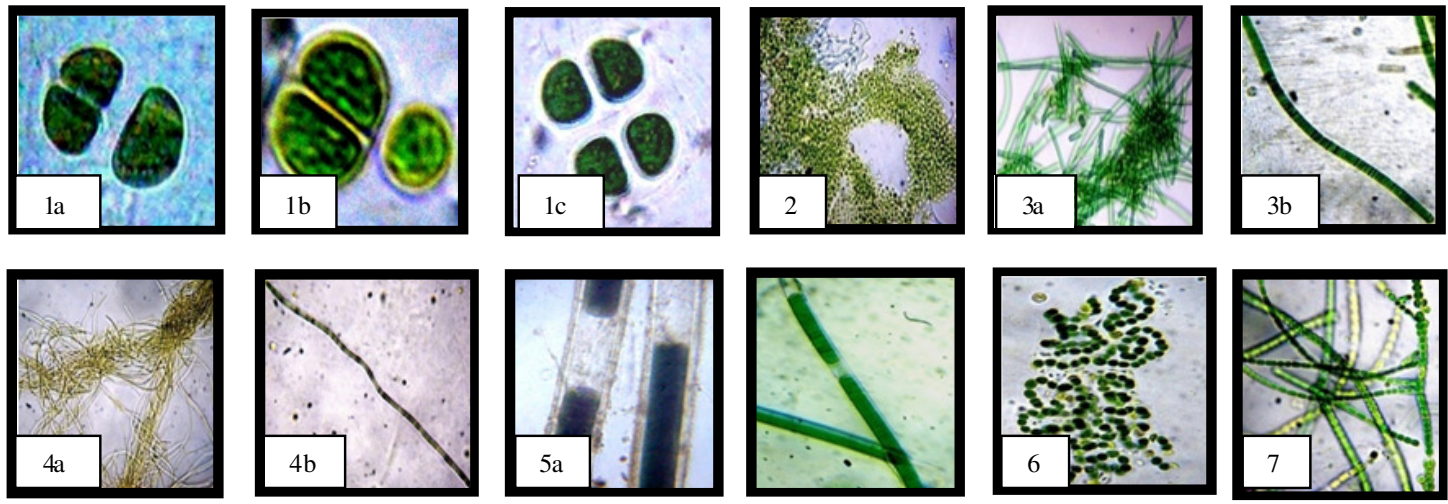

(Figure 1a, b \& c Chroococcus sp., Fig.2 Microcystis sp., Fig.3 a \& b Oscillatoria sp., Fig.4 a \& b Phormidium sp., Fig.5 a \& b Lyngbya sp., Fig.6 Nostoc sp. and Fig.7 Haplosiphon sp.)

\section{References}

Adonis, Giorgi and Leonardo, Malacalza (2001).Effect of an indus trial discharge on water quality and periphyton structure in a pampeam stream.

Ali, M.B., Tripathi, R.D., Rai, U. N., Pal, A. and Singh, S. P. (1999). Physicochemical characteristics and pollution level of Lake Nainital (U.P. India): Role of macrophytes and phytoplankton in biomonitoring and Phytoremediation of toxic metal ions. Chemosphere.39: 217 1-2181

Anand, N. (1998). Indian Fre shwater Microalgae. Bishen Singh Mahendra Pal Singh. Dehra Dun. 1-94.

Boominathan, M. (2005). Bioremediation studies on dairy effluent using Cyanobacteria. Ph.D. Thesis. Bharathidasan University. Tiruchirapalli. Tamil Nadu. India.

Booth, W. E. (1941). Algae as pioneers in plant succession and their important in erosion control. Ecology 22: 38-46.

Bristol, R.B.M. (1927).On carbon nutrient of some algae isolated from soil. Annals of Botany41:509-517.

Desikachary, T.V. (1959). Cyanophyta. Indian Council of Agric. Research, New Delhi, 686.
Dwivedi, S., Mishra, P. K., Tripathi, R. D., Rai, U. N., Dwivedi, C. P., and Baghel, V. S., et al. (2005).

Systematic and ecological studies on Chlorophyceae of North India and the ir relationship with water quality. Journal of Environmental Biology. 26: 495-503.

Forsberg, A., Soderlund, F. A., Pettersson, L., and Pedersen, P. (1988). Studies on metal content in the brown seaweed Fucus vesiculosus, from the archipelago of Stockholm. Environmental Pollution. 49: 245-263.

Fritsch, F.E. (1907). The role of algal growth in the colonization of new ground and in the determination of scenery. Geographic. Jour. 30:53 1-548.

Fritsch, F. E. (1922). The terrestrial algae. Journal of Ecology. 10:220-236.

Fritsch, F.E. and John, R.P. (1942). An ecological and taxonomic study of algae of British soils II consideration of the species. Annals of Botany6:371-395.

Gantar, M., Gajin, S. and Dalmacija, B. (1984). The possibility of phosphate elimination by the use of algae in the process of waste water purification. Microbiologica. 21:63-73.

Gupta, P. K. (2001). Methods in Environmental Analysis Water, soil and Air. 
Gupta, V. K., Shrivastava, A. K. and Jain, Nee raj (2001). Biosorption of Chromium (VI) From Aqueous solutions by green algae spirogyra species. Water Research. 4079-4085.

John, R.P. (1942). An ecological and taxonomic study of the algae of British soils I. The distribution of surface growing algae. Annals of Botany6:323-349.

Kelly, M. (1988). Mining and the fresh water environment. Netherlands: Elsevier, Applied Scie nce.

Lewin, R.A. (1956). Extracellular products of green algae. Canadian Journal of microbiology9: 305-313.

Lund, L.G.W. (1962). Soil algae. In physiology and biochemistry of algae ed. Lewin R.A. Academic press London and New York 759-765.

Murugesan, S. and Subramanian, V. Siva (2005). Cyanobacteria of Porur Lake. Chennai. Tamilnadu. Indian Hydrobiology. 8(1): 49-54.

Nazneen, S. (1980).Influe nce of Hydrobiological factors on the seasonal abundance of phytoplankton in Kinjhar Lake. Pakistan. Intl. Reuse Ges. Hydrobiol. 62(2):269-282.

Prescott, G. W. A. (1951). Algae of the western Great lakes area. Cranbrook Institute of Science. Bulletin. 31:946.

Petersen, J.B. (1935). Studies on biology and taxonomy of soil algae Dansk 8: 1-8.

Rai, L.C. and. Kumar, H.D. (1977).Studies on the seaso nal variations in the algal communities of a pond polluted with fe rtilize r factory efflue nt. Indian J. Ecol. 4(2): 124-131.

Rai, U. N., Dubey, S., Shukla, O. P., Dwivedi, S. and Tripathi, R. D. (2007). Screening and identification of early warning algal species for metal contamination in fresh water bodies polluted. Environ. Monit. Assess.

Rai, U. N., Dwivedi, S., Tripathi, R. D., Shukla, O. P., and Singh, N. K. (2005). Algal biomass: An economical method for removal of chromium from tannery effluent. Bulletin of Environmental Contamination and Toxicology.75: 297-303.
Shapiro, B. M. and Stadtman, E. R. (1970). Glutamine Synthatase (E.coli), in Methods in enzymology XVII A, edited by $\mathrm{H}$ Tabor \&C W Tabor (Academic Press, London). 910-922.

Singh, B. K., Dhar, D. W., Pubbi, S., Prasanna, R. and Arora, A. (2007). BGA, Azolla Biofertilizers- A Manual for their production Evaluation and Utilization.

Singh, R. N. (1950). Reclamation of Usar land in India through blue green algae. Nature.165: 325-326.

Singh, R.N. (1961). Role of blue green algae in nitrogen economy of Indian agricultural. ICAR. New Delhi.

Singh, V.P. and Saxena, P.N. (1969). Preliminary studies on algal succession in raw and stabilized sewage. Hydrobiologia. 34:503-512.

Smith, G.M. (1950). The fresh-water algae of the United States. McGraw-Hill, London.719.

Subramanian, V., Nooruddin Thajudd in and Chokkaiya Manoharan. (2007). Biodive rsity of Cyanobacteria in industrial effluents. Acta Botanica Malacitana.32:1-8.

Trivedi, R. K.and Goel, P.K. (1986).Chemical and Biological Methods for water pollution studies.Published by Environmental publications, Karad (India).

Venkateswarlu, V. (1969). An ecological study of the algae of the Moosi River. Hyderabad (India) with special reference to Water Pollution Part I Physico-chemical Complexes. Hydrobiol. 33(1): 117-143.

Venu, P., Kumar, V., Sardana, R.K. and Bhasin, M. K. (1984). Indicatory and functional role of phytoplankton in the effluents of rangpo distille ries of Sikkim Himalayas. Phykos. 23(12): $38-44$

Vijayakumar, S., Thajuddin, N. and Manoharan, C. (2005). Role of Cyanobacterian the treatment

Xue, H. B. and Sigg, L. (1990). Binding of Cu (II) to algae in a metal buffer. Water Research.24:1129-11 